Nama : Junaena Deka Parameswari

NRP : 130119009

\title{
PENTINGNYA INOVASI DAN KREATIVITAS ERA TEKNOLOGI DIGITAL
}

Indonesia hingga kini dan ke depan masih memiliki daya tarik besar di mata investor dan pebisnis, hal ini antara lain tercemin dari aliran dana ke instrumen portofolio di pasar keuangan dan pasar modal.

Patut dicermati bahwa perekonomian Indonesia pada 2019 pasca pemilu mulai membentuk kenormalan baru menyusul berkembangnya digital economy dan leisure economy yang akan menciptakan peluang dan bisnis baru pada 2020. Pebisnis yang survive di era kenormalan baru ini adalah mereka yang mampu menghasilkan produk atau layanan yang more for less, artinya perusahaan harus memberikan more kepada pelanggan dengan less invesment. Dengan demikian, perusahaan memang dituntut untuk lebih dekat dengan pelanggan guna menghadapi iklim persaingan usaha yang kian ketat.

Hasil dari penelitian menggunakan metode kualitatif deskriptif dengan pendekatan studi kasus dalam rangka menganalisis secara keekonomian kondisi eksisting bisnis dan pemasaran di Indonesia era industri 4.0 yaitu penggunaan teknologi informasi dan big data melalui artifical inteligence terbukti mampu memperpendek rantai komunikasi dari pemasar ke pengguna akhir sehingga jalur distribusi menjadi lebih pendek, penggunaan gudang penyimpanan makin hemat, tidak perlu melibatkan tenaga penjualan yang terlalu banyak, dan semakin mudah menentukan psikografis pelanggan dan jenis pronasi, termasuk cara beriklan dan penentuan inovasi produk atau jasa baru jika diperlukan. Dengan kata lain, branding harus terus berjalan melalui penataan kembali potensi dan kekuatan yang dimiliki, konsolidasi merek, serta senantiasa kreatif dengan berinovasi sesuai kebutuhan dan keinginan konsumen. Hasil penelitian menunjukkan bahwa inovasi yang telah dijalankan baru sebatas pada pengembangan produk atau kemasan, dan bukan perubahan dalam arti menyeluruh; begitu pula penggunaan teknologi belum tergolong hal yang baru. Kebanyakan masih pada tataran menggabungkan hal - hal yang sudah ada dan dimodifikasi, seperti produk - produk minuman, sabun cuci, dan produk - produk yang tersaji di super market, hyper market, dan mini market.

Berdasarkan hasil wawancara dan observasi ternyata cara paling efektif adalah membangun suatu budaya atau menjalankan suatu program adalah dengan melibatkan leaders dan membuka jalur komunikasi yang selebar - lebarnya tanpa proses instan. Semua karyawan senantiasa diberi kebebasan untuk menyalurkan ide dan inovasi sehingga karyawan akan memberikan sesuatu yang terbaik bagi perusahaan, mengingat perilaku konsumen telah mengalami perubahan akibat pengaruh teknologi digital. konsumen menjadi lebih mudah membandingkan antarmerek dan tidak bisa lagi hanya dijadikan target semata. Saat ini konsumen tampak semakin pintar dengan pilihan produk yang semakin banyak, dan bahkan memiliki kekuatan yang semakin tinggi.

Perubahan begitu besar terkait perilaku konsumen membuat perusahaan membutuhkan marketeer yang memiliki kemampuan techincal skill, soft skill marketing, personality traits, dan 
empathy. Kemampuan empati dari seorang marketeer sudah tak terelakkan lagi, yakni keterampilan untuk bisa menangkap insight - insight yang relevan dari target pasar, mengambil sari - sari dari hal yang paling mendasar dan paling mengena bagi konsumen. Begitu pula marketeer dituntut untuk memiliki kemampuan menganalisis data dan problem solving yang acapkali berdasar pada kreativitas. Creative skill sangat dibutuhkan untuk mengontekstualisasikan ide - ide pemasaran ke hal - hal yang relevan dalam berbagai pesan pemasaran. Subconscious Mind tentu akan terpacu oleh hal - hal familiar yang ada dalam ide baru ini, mengingat Subconscious Mind diperkirakan bisa memproses informasi hingga 400 milliar bit per detik. Derasnya informasi yang diterima konsumen setiap hari harus diimbangi dengan kemampuan untuk mempengaruhi agar konversi penjualan meningkat.

Sebaiknya strategi dan program selalu dikaji ulang secara periodik dan disesuaikan dengan kondisi guna mempertahankan pengembangan bisnis dan branding perusahaan. Hingga kini sejumlah pelaku usaha masih mengeluhkan proses perizinan dengan persyaratan yang tidak mudah, seperti regulasi terkait ketenagakerjaan serta sertifikasi laik fungsi untuk sektor usaha perhotelan dan properti, termasuk sertifikasi halal untuk produk-produk seperti makanan, minuman, farmasi, serta kosmetika dan kecantikan.

Referensi : Tayibnapis, Ahmad Zafrullah and Wuryaningsih, Lucia Endang and Gora, Radita (2019) Pentingnya Inovasi Dan Kreatifitas Era Teknologi Digital. In: Seminar Nasional Manajemen dan Call Paper (SENIMA 4), 5 Oktober 2019, Hotel Ibis Styles Jln. Jemursari, Surabaya. 